\title{
Emerging Asia's Version of the Mundell-Fleming Model
}

\author{
Suresh Ramanathan", Kian Teng \\ Economics Department, Faculty of Economics and Administration, University Malaya, Kuala Lumpur, Malaysia \\ Email: "skrasta70@hotmail.com,ktkwek@um.edu.my
}

Received July 17, 2013; revised August 7, 2013; accepted August 13, 2013

Copyright (C) 2013 Suresh Ramanathan, Kian Teng. This is an open access article distributed under the Creative Commons Attribution License, which permits unrestricted use, distribution, and reproduction in any medium, provided the original work is properly cited.

\begin{abstract}
This paper explains the Mundell-Fleming model in the context of Emerging Asia economies management of capital mobility. Central Banks and Financial Regulators in Emerging Asia adopt a modified version of the model that incorporates two vital levers, a policy driven and a market driven method that is adaptable to the magnitude of capital flow. A policy combination mix of both policy and market driven provides smooth monetary policy signal transmission to exchange rates.
\end{abstract}

Keywords: Mundell-Fleming Model; Capital Mobility; Foreign Exchange Markets; Monetary Policy; Emerging Asia

\section{Introduction}

Stable exchange rates, independent monetary policy and free capital flow, the trilemma or impossible trinity, suggest that only two of the above three objectives can be accomplished simultaneously according to Fleming and Mundell (1962 and 1963) [1,2]. In assessing the trilemma, findings by Mankiw (2010) [3] indicate China managed to achieve stable exchange rates and independent monetary policy that was accompanied by capital controls. But can the trilemma be considered as a guide for macroeconomic policy framework? Obstfeld et al. (2005) [4] suggest economies that are without a pegged exchange rate and have barriers to capital mobility can retain sufficient amount of monetary policy independence whereas economies with pegged exchange rates and do not have barriers to capital mobility would lose significant monetary policy independence. In a case study by Yu Hsing (2012) [5] on selected EA economies, findings in support of trilemma were evident in Malaysia, Philippines and Singapore, while there was no evidence of a trilemma situation in Indonesia and Thailand. Different macroeconomic policy combinations prevailed in Malaysia, Philippines and Singapore, rendering the ability to switch to different policy combination over time in order to deal with major economic events. In conceptualizing the Mundell-Fleming model within the trilemma objective, it is pertinent to take into account the risk premium element in the form of barriers to capital mobility. In EA foreign

\footnotetext{
${ }^{*}$ Corresponding author.
}

exchange markets, barriers to capital mobility play a significant role in managing the overall macroeconomic policy framework. There are two key aspects of the EA version of the Mundell-Fleming model, the market and policy-driven space.

\section{The Model}

The Mundell-Fleming model for EA incorporates market-driven, $D$ point and policy-driven. $E$ point (see Figure 1).

In the context of the standard model, points $A, B$ and $C$ remain, indicating the choice for central banks and financial regulators being limited to adhering only two points of preference, where the distance between $A$ to $C$ being exchange rate fixing, $A$ to $B$ as monetary policy independence and $B$ to $C$ as free capital mobility. In EA a strict proposition of the Mundell Fleming model is a constrain for central banks and financial regulators following the lessons learnt during the 1997/98 Asian Financial Crisis. Consistent with this objective, Aizenman et al. (2011a) [6] finds that for developing economies, maintaining exchange rate stability was a key priority up to the period of 1990, and since 2000, developing economies pursued managed exchange rate flexibility and retained partial monetary policy independence. The task of managing capital mobility is to keep it in line within the macroeconomic policy framework of the domestic economy, therefore, the introduction of points $D$ and $E$. The midpoint of $D$ to $E$ is a policy combination mix where the degree of capital mobility between $A$ to $D$ 


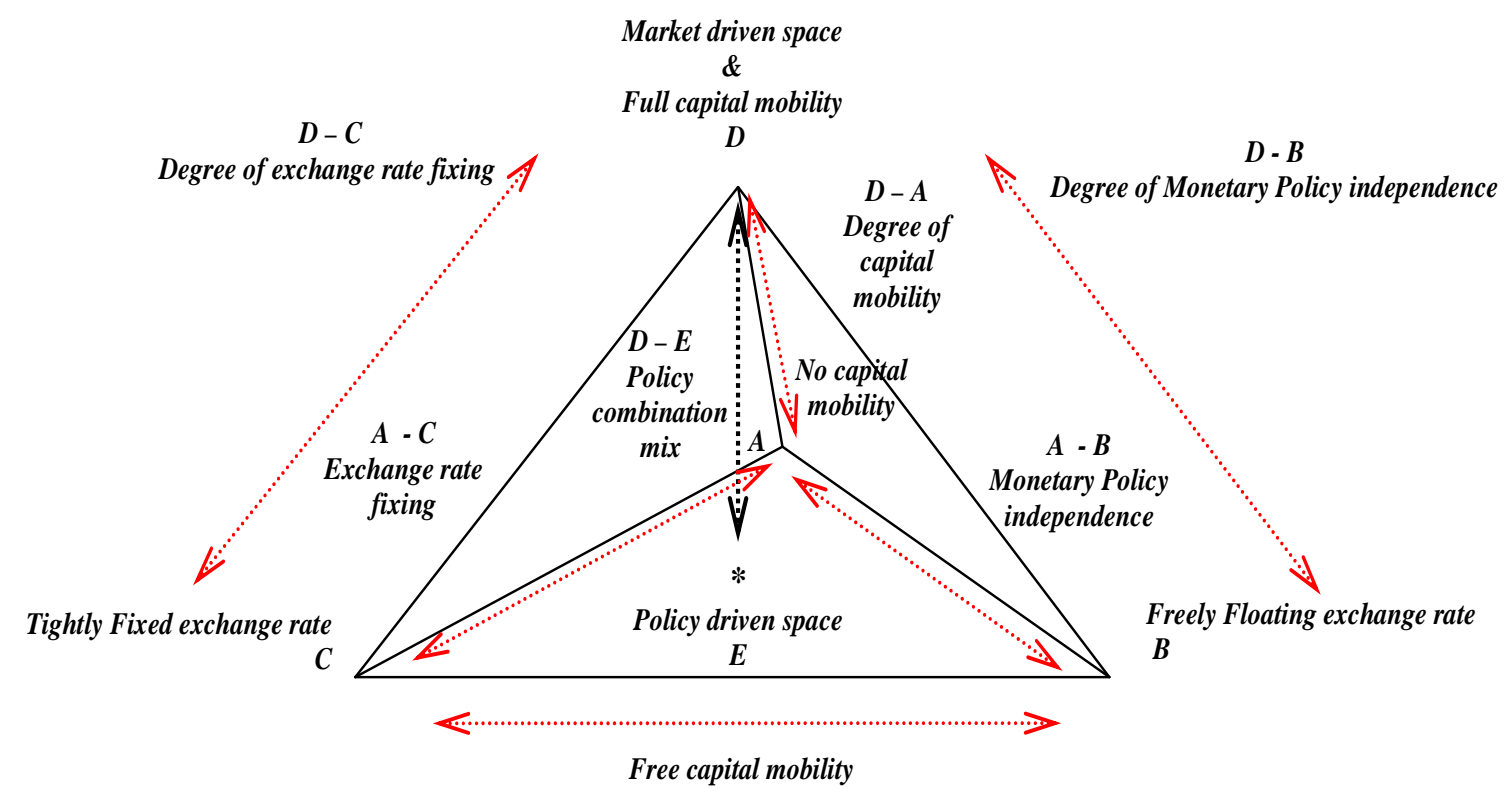

Figure 1. Emerging Asia Mundell-Fleming model.

is adjusted using the policy combination mix. The management of capital flow in EA financial markets though is within the same plane of $A$ and $E$, the adjustment process for central banks and financial regulators is done via the distance between $D$ to $E$. As $E$ stays as the centre of the Mundell-Fleming model, the point $E$ would interface with points $D$ and $A$. The flow of policy is captured between a no capital mobility point of $A$ or a full capital mobility point of $D$ (see Figure 2).

In both extreme cases, point $E$ plays an integral role of adjusting the policy-driven space. The policy combination mix takes into account the external and internal environment and the adjustment is done accordingly. Within the framework of the Mundell-Fleming model and taking into account of points $A, D$ and $E$, the distortion to capital mobility in the EA framework is identified by incorporating risk premium on capital mobility. Risk premium in the form of barriers to capital mobility $p$ which is the the interest rate that onshore investors must pay to foreign investors. The risk-free rate in the economy, $y$ is the premium that foreign investors must pay to domestic investors for parting with liquidity. In the Mundell-Fleming model, $r$ is determined in the money market for a given real output, prices, and money supply. Given the risk premium, the exchange rate $e$ incorporates $p$, implying barrier of capital mobility that foreign investors face in investing in the domestic financial market.

Therefore risk premium

$$
\dot{p}=f(r, e) \text {. }
$$

where $f_{r}>0$ and $f e>0$. Higher interest rates $y$ in the case of tightening of monetary policy in the economy results in an increase in the capital mobility risk premium

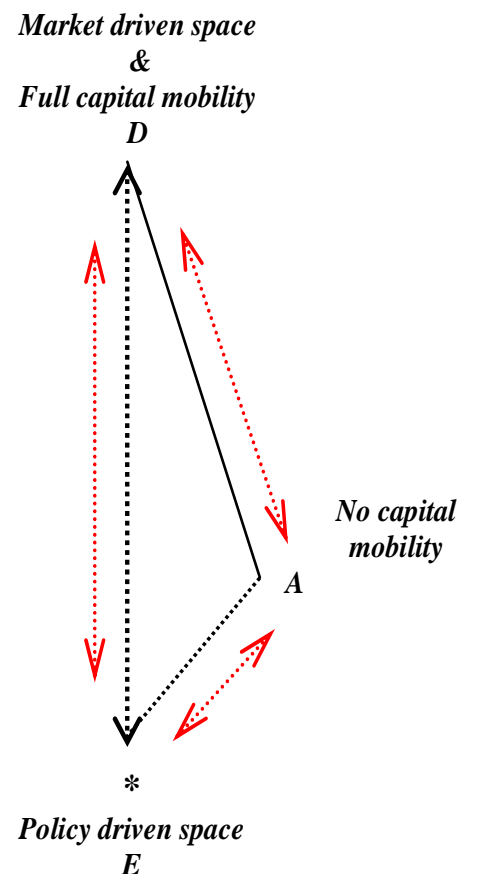

Figure 2. Market driven, policy driven, capital mobility.

$p$ and depreciation of the exchange rate is priced into the capital mobility risk premium. As $e$ increases it is identified as exchange rate depreciation and as $e$ decreases it is identified as exchange rate appreciation.

The model incorporates aggregate demand and supply as reflected by the $I S$ curve, given as

$$
Y=D(Y, r, e)+G+N X(Y, e)
$$

where,

$$
D_{e}+N X_{e}>0
$$


If, $e<\hat{e}$

The equilibrium in the money market is reflected by the $L M$ curve as

$$
M / P=L(r, Y)
$$

The price level $P$ is an exogenous component while monetary policy is conducted by changing the money supply $M$.

The balance of payments or the $B P$ curve is identified as

$$
B P=N X(Y, e)+K A\left(r-r^{*}, \dot{p}^{-} \dot{p}^{*}\right)
$$

where,

$$
N X_{e}+K A_{p} p_{e}>0
$$

If $e>\hat{e}$

where $r^{*}$ and $\dot{p}^{*}$ is the interest rate and risk premium at equilibrium, whereby

$$
K A_{r}+K A_{p} p_{y}>0
$$

If $y<r^{*}$

And net exports $N X$ have a positive relationship between income $Y$ and the exchange rate $e$.

In the Mundell-Fleming model, capital flows $K A$ increase when interest rate differentials $y-r^{*}$ widen. Gray and Malone (2008) [7] indicate, in the case of risk premium differences $\dot{p}-\dot{p}^{*}$ which widens, capital flow will decrease given the risk of decline in investments and general risk aversion to investments.

The standard BP model in the Mundell-Fleming model while applies in a free capital mobility framework is instead curved in the context of EA financial markets when it incorporates points $A, D$ and $E$. Given the backward bending $B P$ curve, two equilibriums exists for each value of the exchange rate when taking the $I S$ curve as fixed. The first equilibrium at point $F$ occurs when $y^{a}<r^{*}$ at the lower half of the $B P$ curve and the second equilibrium is at point $G$ when $y^{b}>r^{*}$ at the upper half of the $B P$ curve (see Figure 3).

Appropriate fiscal and monetary policy is used to obtain any point along the $B P$ curve but it will be impossible to achieve a level of output higher than point $H$ on the $B P$ curve without causing exchange rate depreciation. For a given exchange rate $\hat{e}$, the money supply necessary to obtain point $F$ equilibrium is by $M^{A}(\hat{e})$, and the money supply necessary to obtain point $G$ equilibrium is by $M^{B}(\hat{e})$. Caballero and Panageas (2005) [8] indicate that the backward bending IS curve occurs if households practice precautionary savings and reduce consumption in response to capital mobility risk premium being incorporated into the exchange rate. Corresponding with the ISBP curve, equilibrium in the output and foreign exchange market comprises of two backward bending curves. In such circumstances with fiscal and monetary policy, two equilibrium exchange rates exists, one low and other high, referred as $e^{L}$ and $e^{H}$. The two vertical

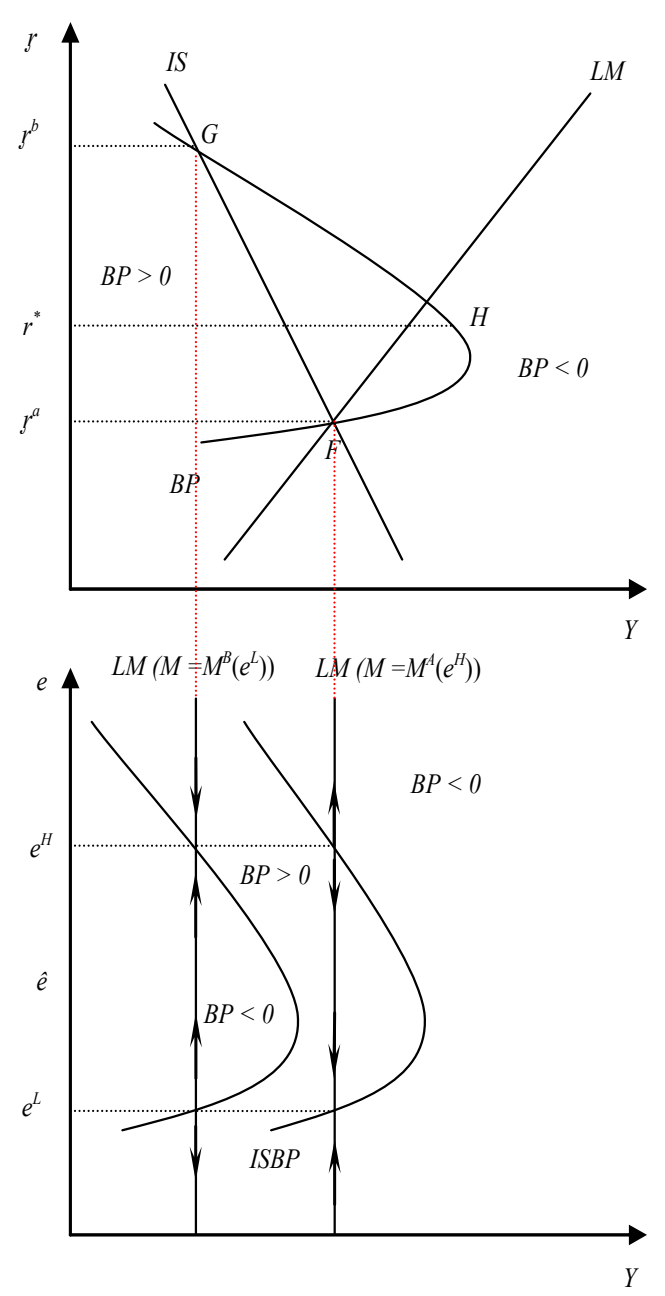

Figure 3. Changes in monetary policy and risk of exchange rate disequilibrium.

lines of the $L M$ curve is consistent with monetary policies of

$$
M=M^{B}\left(e^{L}\right)
$$

and

$$
M=M^{A}\left(e^{H}\right)
$$

The arrows on the $L M$ curve indicate the direction of movement of exchange rates that is out of equilibrium where the space left of the ISBP curve intersects in two places with the $G$ equilibrium on the $L M$ curve, the $B P<$ 0 , and exchange rates are increasing. In the space between the left hand and right hand of the ISBP curve, the $B P>0$, exchange rates are decreasing. To the right of the right hand of the ISBP curve which intersects in two places with $F$ equilibrium on $L M$ curve, the $B P<0$ and exchange rates are increasing.

In an environment of tight monetary policy corresponding with $M=M^{B}$ and $y^{b}>r^{*}$, the stable equilibrium for exchange rates is at $e^{H}$, but is unstable for exchange 
rate $e^{L}$ which indicates as monetary policy is tightened and given the risk premium to capital mobility, maintaining an exchange rate appreciation will be difficult. In the case of easing of monetary policy with $M=M^{A}$ and $r^{a}$ $<r^{*}$, the stable equilibrium for exchange rates is at $e^{L}$ but is unstable for exchange rate $e^{H}$ as excessively loose monetary policy could induce a currency crisis.

\section{Conclusion}

In EA with capital mobility being a factor that shapes macroeconomic prudential policies, the risk of tightening and loosening of monetary policy bears a significant impact on the direction of exchange rates. The importance of the Mundell Fleming Model in the context of EA is twofold. First, the imposition of barriers to capital mobility could amplify the impact on exchange rates when monetary policy is tightened or loosened. Second, the risk premium on capital mobility can be reduced gradually by carefully implementing a policy combination mix in order to transmit smooth monetary policy signal to exchange rates.

\section{REFERENCES}

[1] J. M. Fleming, "Domestic Financial Policies under Fixed and Floating Exchange Rates," IMF Staff Papers, Vol. 9, 1962, pp. 369-379. doi:10.2307/3866091

[2] R. A. Mundell, "Capital Mobility and Stabilization Policy under Fixed and Flexible Exchange Rates," Canadian Journal of Economic and Political Science, Vol. 29, No. 4, 1963, pp. 475-485.

[3] N. G. Mankiw, "The Trilemma of International Finance," New York Times, 1 July 2010.

[4] M. Obstfeld, J. C. Shambaugh and A. M. Taylor, "The Trilemma in History: Tradeoffs among Exchange Rates, Monetary Policies, and Capital Mobility," Review of Economics and Statistics, Vol. 87, No. 3, 2005, pp. 423-438. doi: $10.1162 / 0034653054638300$

[5] Y. Hsing, "Test of the Trilemma for Five Selected Asian Countries and Policy Implications," Applied Economics Letters, Vol. 19, No. 17, 2012, pp. 1735-1739. doi:10.1080/13504851.2012.667542

[6] J. Aizenman, M. D. Chinn and H. Ito, "Surfing the Waves of Globalization: Asia and Financial Globalization in the Context of the Trilemma," Journal of the Japanese and International Economies, Vol. 25, No. 3, 2011, pp. 290320. doi:10.1016/j.jjie.2011.06.003

[7] D. Gray and S. Malone, "Macrofinancial Risk Analysis," 2008. doi:10.1002/9781118467428

[8] J. Ricardo, G. Caballero and S. Panageas, "Contingent Reserves Management: An Applied Framework," Journal Economía Chilena (The Chilean Economy), Vol. 8, No. 2, 2005, pp. 45-56. 